\title{
COMBATING CRIME WITH THE HELP OF CRIMINALISTICS
}

\author{
EVGENY SMAKHTIN, \\ Tyumen State University (Tyumen, Russia) \\ ROMAN SHARAPOV, \\ St. Petersburg Law Institute (Branch) of the Federal Establishment \\ of Higher Education University of the Office of the Prosecutor of the Russian Federation \\ (St. Petersburg, Russia)
}

DOI: $10.21684 / 2412-2343-2018-5-4-155-174$

This comparative study examines the issue of combating crime with criminalistic methods. It focuses on the role and significance of criminalistics in the system of substantive and criminal procedural law as a science standing at the forefront of the fight against crime. The criminals and their offenses as well as the investigation of criminal cases and judicial proceedings are the objects of the analysis. The correlation between the criminal sciences and general trends in the development of a number of European and BRICS countries (with China as an example) has been emphasized. Joint research into the most pressing problems of combating crime is believed to improve the efficiency of law enforcement activities. From this perspective, there is a need to develop a universal framework of categories and concepts which will help to create a unified forensic area in Europe and the BRICS countries.

Keywords: criminal law; criminal proceedings; criminalistics; crime; offender; characteristics; trace.

Recommended citation: Evgeny Smakhtin \& Roman Sharapov, Combating Crime with the Help of Criminalistics, 5(4) BRICS Law Journal 155-174 (2018).

\section{Introduction}

The globalization of the world economy and joint projects conducted by different countries in a number of spheres including the fight against crime necessitate an 
understanding of counter-crime methods and means. There are several different mechanisms with which to combat international crime. Traditionally, the most significant tools in this fight are the instruments in the fields of criminal substantive law, criminal procedure and criminalistics. However, the approaches to the definition of the same concepts, both in science and in practice, differ throughout the world. For example, the countries with the Anglo-Saxon legal system make use of the term "forensic science," which is defined as the application of scientific methods to legal matters, civil and criminal cases.' In France, Belgium and some other European countries, the terms "scientific police," "police techniques" and "technical police" are used; they relate to a set of methods and techniques for detecting and fixing traces left at a crime scene. ${ }^{2}$

In addition, European countries have also developed a broader concept of "police science" which covers the full spectrum of police matters, including crime investigation. Germany and countries of Eastern Europe use the term "criminalistics" to define the doctrine of methods and means of combating certain crimes and crime in general through preventive and repressive measures. ${ }^{4}$ At the turn of the $20^{\text {th }}$ century, Russian scientists were greatly influenced by their German colleagues, thus the first books on criminalistics in Russia were translated from German into Russian ${ }^{5}$ and the term "criminalistics" became widely accepted, both in theory and in practice.

In the East, for example in the People's Republic of China, the use of special knowledge in the course of criminal case investigation and hearings is also widespread. ${ }^{6}$ Finding promising areas in the study of crime in $\mathrm{China}^{7}$ that are systematic and comprehensive ${ }^{8}$ is of increasing interest to scientists and practitioners.

Suzanne Bell, Encyclopedia of Forensic Science 162 (Revised ed., New York: Facts on File, Inc., 2008).

2 Хаткевич Е.П. Сравнительная характеристика представлений о судебной науке, криминалистике и смежных понятий в странах Европы // Криминалистика и судебная экспертология: наука, обучение, практика [Elena P. Khatkevich, Perception of Forensic Science, Criminalistics and Related Concepts in European Countries: Comparative Analysis in Criminalistics and Judicial Expertology: Science, Training and Practice] 93-94 (Vilnius: Nicolo Ramiros University, 2013).

3 Hans-Gerd Jaschke et al., Perspectives of Police Science in Europe: Final Report, CEPOL (April 2007), at 23-24 (Nov. 2, 2018), available at https://www.cepol.europa.eu/sites/default/files/website/Research _ Science/PGEAPS_Final_Report.pdf.

4 Hinrich de Vries, Ist die Kriminalistik eine Wissenschaft, 3 SIAK-Journal - Zeitschrift für Polizeiwissenschaft und polizeiliche Praxis 27, 28 (2010).

5 Вейнгарт A. Уголовная тактика. Руководство к расследованию преступлений [Albert Weingart, Criminal Tactics. A Guide to Investigating Crimes] 272 (V.I. Lebedev (ed.), St. Petersburg: Bulletin of Police, 1912).

6 Лэй Т. Судебная экспертиза в уголовном процессе КНР и СССР (опыт сравнительного исследования): Автореф. дис. ... канд. юрид. наук [Tan Lei, Forensic Examination in Criminal Proceedings of the PRC and USSR (Experience of Comparative Research): Synopsis of a Thesis for a Candidate Degree in Law Sciences] 20 (Voronezh, 1991).

7 Lin Liu \& Jessica C.M. Li, Progress and Future Directions of Crime Research in China with Selected Case Studies, 4(1) Journal of Research in Crime and Delinquency 213 (2017).

8 Kam C. Wong, The Study of Criminology in China: Historical Development: Part l, 44(3) China Report 213 (2008). 
We easily notice that the highlighted terms differ in name as well as in content. However, they all share similarities. In fact, they refer to the use of special methods, tools and techniques for fighting crime; all the branches of scientific knowledge mentioned above are supposed to have common objects of cognition. Specifically, all scientists, regardless of the country, identify criminal activities and police actions aimed at investigating crime as objects of study.

Since criminal sciences share common objects of cognition, it is necessary to specify and differentiate their subject areas. This is due in part to the improvement of information technology used both in the commission of a criminal act and in the investigation of crime. Therefore, it seems important to determine the content of the regularities that are included in the subject of criminalistics, to define its place in the general system of the criminal sciences and to develop common approaches to the definition of the same terms in the science of crime.

This article aims to reveal the main laws that are part of criminalistics in Russia and to identify the possible directions of scientific cooperation with international colleagues. The intended objective predetermines the tasks which will be resolved by exploring the objects of knowledge and clarifying the definitions of certain concepts in criminalistics. More specifically, the authors attempt to define the mechanisms relating to the commission of crimes, their criminalistic characteristics, and some other matters as well.

The assumption to proceed with is that the object has a certain reality knowable in the process of scientific activity. In its turn, the subject stands for "some integrity identified while learning"' about the object.

As the targets of the research, the authors have identified the crime (criminal activity) and the criminal, as well as the activities for investigation of the crime and judicial review, the latter being the two types of human activity viewed through the prism of the system-activity approach. These two types of human activity constitute the dual object of cognition in criminalistics.

\section{Crime (Criminal Activity) and Criminals as an Object of Cognition of Criminalistics}

\subsection{The Origin of Criminalistics as a Science. Scientific Discussions of its Subject Matter}

In the $19^{\text {th }}$ century, in several European countries scientists focused on the problems of combating crime, which were difficult to explain in terms of substantive and procedural criminal law. The "birth" of criminalistics as a science is associated with the name of the Austrian scholar Hans Gross. He managed to systematize fragmented

9 Возгрин И.А. Объект, предмет и понятие криминалистики // Вестник Санкт-Петербургского университета МВД России. 2000. № 4(8). С. 68 [Igor A. Vozgrin, The Object, Subject and Concept of Criminalistics, 4(8) Bulletin of St. Petersburg University of the Russian Interior Ministry 68 (2000)]. 
knowledge and propose a system of a new science. With regard to the object of cognition under consideration, Gross succeeded in substantiating the need to study the techniques used by criminals, Thieves' Cant (thieves'language), various types of simulations and false testimony, secret signs among criminals as well as superstitions regarding, among other things, objects left at the crime scene. ${ }^{10}$

In Russia, I. Yakimov also studied the data characterizing criminal activities and the criminal: the types of criminals and their customs; the existing categories of criminals by type of crime in the context of the criminal law; and common tricks used by criminals. In addition to the classification of criminals, the impact of prostitution, alcoholism, drug addiction and the nature of criminals on crime activities was investigated."

Other Russian criminalists also emphasized how important it was, when investigating a crime, to be aware of the criminal's traits of character and experience. ${ }^{12}$

The study of crime and the criminal required the differentiation of subject areas in the sciences of substantive law, criminal procedural law and criminalistics, since all of them dealt with the object of cognition to some extent.

For example, M. Strogovich believed that only "scientific methods of detecting and investigating material evidence and traces of crime, i.e. techniques borrowed from the natural and technical sciences and adapted to use in the investigation of crimes, ${ }^{\prime \prime 13}$ could be the subject of criminalistics. The well-known professor defended his position for quite a long time, but softened it in the 1960s. ${ }^{14}$

No less famous a scientist, the processualist M. Cheltsov, sharing the views of Strogovich, noted that

the subject of criminalistics is only the technique of detecting, fixing, and processing material evidence. ${ }^{15}$

This reaction to the definition of the subject of criminalistics on the part of the above-mentioned processualists is quite understandable, as questions of tactics and

10 Гросс Г. Руководство для судебных следователей как система криминалистики [Hans Gross, A Manual for Forensic Investigators as a Forensic System] 346-514 (Moscow: LeksEst, 2002).

11 Якимов И.Н. Криминалистика. Руководство по уголовной технике и тактике [lvan N. Yakimov, Criminalistics. Manual on Criminal Techniques and Tactics] 229-247 (Moscow: LeksEst, 2003).

12 Громов В.И. Дознание и предварительное следствие. Методика расследования преступлений. Осмотр места преступления [Vladimir I. Gromov, Inquiry and Preliminary Investigation. The Methodology for Investigating Crime. Examination of the Crime Scene] 453-465 (Moscow: LeksEst, 2003).

13 Строгович М.С. Труды Военно-юридической Академии Красной Армии [Mikhail S. Strogovich, Proceedings of the Military-Law Academy of the Red Army] 6 (Moscow: Gosyurizdat, 1942).

14 Строгович M.C. Уголовный процесс [Mikhail S. Strogovich, Criminal Procedure] 22 (Moscow: Gosyurizdat, 1958); Строгович М.С. Курс уголовного процесса [Mikhail S. Strogovich, The Course of Criminal Procedure] 101-102 (Moscow: Gosyurizdat, 1968).

15 Уголовный процесс: Учебник [The Criminal Procedure: Textbook] 32 (Moscow: Gosyurizdat, 1948). 
methods of investigating crimes at that time belonged to the subject of the science of criminal procedure. Naturally, the scientific research carried out by criminologists, who in one way or another were connected with the problems arising in the crime investigation, was regarded by those and some other scientists as an attempt to unreasonably "invade" the area of evidence.

The analysis of theoretical studies conducted in the middle of the $19^{\text {th }}$ century testifies that criminalistics met all the requirements typical of an independent branch of scientific knowledge. Thus, contrary to what the processualists stated, the role of an auxiliary, exclusively technical discipline, firstly, did not correspond to the objective reality, that is, to existing scientific developments. Secondly, the adoption of that point of view meant nothing more than a return to the first definitions of the subject matter of criminalistics.

Such a decision no longer corresponded to the realities of the time and hampered the development of criminalistics. In the opinion of some criminalists, scientists in the field of criminal procedural law would have reduced the investigation methodology to the consideration of the circumstances to be proven for various types of crime, and the investigative tactics would only illustrate the procedure of the investigation. ${ }^{16}$

The significance and systemic nature of criminalistics were shown in its definition given by A. Vinberg. The scientist defined criminalistics as a science "about technical and tactical methods and means of detecting, collecting, fixing and investigating judicial evidence used to solve crimes against law and order, to identify those responsible, and to find ways to prevent crime."17 Obviously, the scientist writes not only about detection and examination, but also about evidence collection and fixation. The definition indicates the technical and tactical nature of the techniques and tools used in evidence management and the sequence of such work, beginning with detection. In addition, there is a reference to the fact that criminalistic methods and tools are used to uncover and prevent crimes.

Of special note is the definition of criminalistics proposed by S. Mitrichev. The scientist writes:

Criminalistics, as a special legal discipline, is a science about technical means, tactical methods and tools used to perform the actions taken in accordance with the criminal procedure law by the judicial and investigative bodies for the evidence detection, collection, recording and examination in order to investigate crimes. ${ }^{18}$

16 Кирсанов 3.И. Теоретические основы криминалистики: Учебное пособие [Zinovy I. Kirsanov, Basic Theory of Criminalistics: Textbook] 20-57 (Moscow: Military Unit 33965, 1998).

17 Криминалистика [Criminalistics] 4 (Moscow: Gosyurizdat, 1950).

18 Митричев С.П. Предмет, метод и система советской криминалистики [Stepan P. Mitrichev, The Subject, Methodology and System of Soviet Criminalistics] 24 (Moscow: Gosyurizdat, 1956). 
The definition contains some amendments. Unlike in all previous concepts, for example, there is an indication that criminalistics is a special legal discipline. Moreover, the authoritative participants in the trial are mentioned - the judicial and investigative bodies that carry out actions to detect, collect, record, examine and evaluate evidence. At the same time, Mitrichev emphasized the internal interconnection of all sections of criminalistics, which complemented one another and in their unity formed scientific investigation methods. ${ }^{19}$

Thus, we can state that in the 1920s-1950s criminalistics in its development went through several stages:

- The emergence of criminalistics as an applied technical discipline;

- The accumulation of empirical material and the formation of the main sections of criminalistics;

- The formation of criminalistics as an independent science. ${ }^{20}$

\subsection{Content Specification for the Subject Matter of Criminalistics in Examining Crime (Crime Activities) and the Criminal}

Further study of the investigated object and the accumulation of knowledge have resulted in the need for a more precise definition for the subject matter of criminalistics and its interdisciplinary links to substantive and procedural criminal law.

For instance, N. Yablokov, examining the criminalistic aspects of organized criminal activities, writes that:

If the criminal law deals with the constituent criminal law acts of this activity and the criminology is concerned with the content, structure, types, causes and conditions contributing to it, then criminalistics investigates the peculiarity of its structural elements, the patterns of their formation and use by criminals in criminal activities as well as the nature of the interlinkages among those elements. ${ }^{21}$

Subsequently, the scientist further elaborated his position, having defined that:

[T]he criminal activity, outlined and normatively described in the Criminal Code, includes all kinds, types and groups of crime provided for by law. In terms of criminalistics, this activity as a system consists of elements. The information on the said elements contained in the traces, the consequences, of

19 Криминалистика [Criminalistics] 5-7 (Moscow: Gosyurizdat, 1959).

20 Kirsanov 1998, at 27.

21 Овчинский В.С., Эминов В.Е., Яблоков Н.П. Основы борьбы с организованной преступностью: Монография [Vladimir S. Ovchinsky et al., The Basics of Fighting Organized Crime: Monograph] 237 (Moscow: Infra-M, 1996); Яблоков Н.П. Расследование организованной преступной деятельности [Nikolay P. Yablokov, Investigations of Organized Crime] 44 (Moscow: Yurist, 2002). 
any criminal activity has mainly an informative and investigative character and provides an idea of its criminalistic features and their interconnections. ${ }^{22}$

Criminalists from Latvia, Ukraine and Russia such as R. Dombrovsky, ${ }^{23} \mathrm{~N}_{\text {. Karpov, }}{ }^{24}$ A. Kaminsky, ${ }^{25}$ A. Kustov, ${ }_{1}^{26}$ A. Lubin ${ }^{27}$ and others greatly contributed to the development of the criminalistic scientific ideas about crime and criminal activity.

In China, scientists began a thorough study of crime and criminal activity after the economic reforms of $1978^{28}$ to a greater extent in criminalistic terms, ${ }^{29}$ notably at the empirical research level. ${ }^{30}$

Probably Professor R. Belkin was most accurate in determining the subject matter of criminalistics in the object under consideration. The scientist focused his attention on the functional side of illegal activities, that is, on the system of relations and actions that form the mechanism of crime. ${ }^{31}$ Without prolonging the discussion, the term "mechanism of committing crime" seems to be more suitable, and it will be used hereinafter.

At the functional side of any illegal activity, the most significant thing is the trace evidence (in a broad sense), characterized not only by different physical traces, but also by non-physical ones that remain in the memory and consciousness of people. Since the investigator's cognition of the crime event is directed to the past, it is

22 Криминалистика: Учебник [Criminalistics: Textbook] 15-16 (N.P. Yablokov (ed.), $2^{\text {nd }}$ ed., Moscow: Yurist, 1999).

23 Домбровский Р.Г. Познание и доказывание в расследовании преступлений: Дис. ... докт. юрид. наук [Reyngard G. Dombrovsky, Cognition and Evidence: Thesis for a Doctor Degree in Law Sciences] 324 (Riga, 1991).

24 Карпов Н.С. Криминалистические основы изучения преступной деятельности: Автореф. дис. ... докт. юрид. наук [Nikifor S. Karpov, Criminalistic Basis of Crime Examination: Synopsis of a Thesis for a Doctor Degree in Law Sciences] 32 (Kiev, 2008).

25 Каминский А.М. Некоторые методологические положения теоретико-криминалистического анализа организованной преступной деятельности // Вестник криминалистики. 2000. № 4(12). C. 60-66 [Alexander M. Kaminsky, Some Methodological Guidelines for the Theoretical and Criminalistic Analyses of Organized Crime, 4(12) Bulletin of criminalistics 60 (2004)].

26 Кустов А.М. Криминалистическое учение о механизме преступления: Дис. ... докт. юрид. наук [Anatoly M. Kustov, Criminalistic Study of Crime Mechanisms: Thesis for a Doctor Degree in Law Sciences] 355 (Moscow, 1997).

27 Лубин А.Ф. Методология криминалистического исследования механизма преступной деятельности: Дис. ... докт. юрид. наук [Alexander F. Lubin, Methodology for Criminalistic Research of Crime Mechanism: Thesis for a Doctor Degree in Law Sciences] 337 (N. Novgorod, 1997).

28 Shanhe Jiang \& Eric G. Lambert, Views of Formal and Informal Crime Control and Their Correlates in China, 19(1) Lambert, International Criminal Justice Review 5 (2009).

29 Jianming Mei \& Mu Wang, Social Change, Crime, and Criminology in China, 23(1) Crime \& Justice International 14 (2007).

30 Liu 2007.

31 Белкин Р.C. Курс криминалистики: Общая теория криминалистики. В 3 т. [Rafail S. Belkin, Criminalistics: General Theory of Criminalistics. In 3 vol.] 116-117 (Moscow: Yurist, 1997). 
retrospective, and the past is learned precisely by the traces left at the scene. It is the trace examination that the investigation of the entire crime event begins with. This reflects both the special nature of criminalistics and the relationship with the criminal law (substantive and procedural).

Often, it is due to the advances in criminalistics that a particular criminal is identified by the traces left behind, his/her actions are properly defined and other tasks of criminal proceedings are successfully solved.

The functional side of the crime or the mechanism of its commission can be represented as a system of the interaction in a crime of persons, material objects and processes. In the mechanism of committing crime, scientists identify the elements, the knowledge of which as well as the knowledge of the regular connections between them provide an information basis for the activities of the investigator and the court. This is the so-called empirical level of cognitive perception of events, phenomena and processes of objective reality associated with crime commission and its mechanism. At this level, there is a further comprehension of the facts obtained and a transition to the theoretical level of cognition which has a certain degree of abstraction. Such an abstract scientific concept forming the substantive sphere of criminalistics in the object studied is the criminalistic characteristics of a crime.

Thus, one of the objects of cognition in criminalistics is the crime (criminal activity) and the criminal; consequently, the subject includes the mechanism patterns of the commission of a crime and the leaving of traces, which collectively form the criminalistic characteristics of the crime.

A few words should be said about such elements of the crime mechanism as the mechanism of trace formation and the identity of the offender. Criminalists pay special attention to its study, as it carries trace information, i.e., criminalistically significant information.

Investigation of the offender's personality on an empirical level, as a rule, takes place in the following sequence: the trace - the criminal - the characteristics of the criminal. It is this algorithm that criminologists use as a basis in shaping the criminalistic characteristics of specific types and groups of crimes, one of the basic elements of which is the identity of the criminal. The theoretical level of cognition involves developing a theory of the criminalistic characteristics of the criminal's personality.

$\mathrm{N}$. Vedernikov can be considered the founder of the criminalistic study of the criminal's personality because he justified the need for its study in criminalistics. ${ }^{32}$ G. Zorin's opinion is also interesting; he reasonably believes that "one of the approaches to the research of a criminal activity is the approach via the identity of the offender, and his/her qualities." It is through the personality that the complex interaction "cause - environment - situation - personality - deeds - concealment" is realized. The person acts not simply as a "repeater," but as an element actively interacting with

32 Ведерников Н.T. Понятие личности преступника // Вопросы предупреждения преступности [Nikolay T. Vedernikov, The Concept of the Perpetrator in Crime Prevention Issues] 22 (Tomsk: Tomsk University, 1967). 
the environment and situation, ensuring selective assimilation of information and the choice of behavior. It is necessary to identify and retrospectively study the criminals' personal deformations and the typical variants of their social conditioning. ${ }^{33}$

The basic universal image of a criminal's personality was described following the results of the research conducted by $\mathrm{R}$. Akhmedshin. ${ }^{34}$

The criminalistic characteristics (model) of a crime make it possible to adapt and implement the scientific research results in practice. The introduction of scientific findings in the practice of investigating and prosecuting criminal cases is an important direction for scientists - criminalists, not only in Russia but also overseas.

Studies of crime models, ${ }^{35}$ drug-related crimes, ${ }^{36}$ corruption $^{37}$ and the identity of young people at risk, conducted in recent years by scientists from China, ${ }^{38}$ are interesting for Russia and European countries.

\section{Investigation and Judicial Examination as the Second Object of Cognition in Criminalistics}

\subsection{Shaping the Views on the Subject of Criminalistics When Examining Investi- gation Activities}

At the beginning of the $20^{\text {th }}$ century, German criminologists, adherents to the ideas of the Austrian scientist H. Gross, reconfirmed the opinion that the subject of criminalistics includes the study of the criminal's and investigator's actions as well. In most cases in the literature, the tactical aspects in the actions of the investigator were revealed first, and then the criminals were described. ${ }^{39}$

In their works, Russian scientists committed to the ideas of their foreign colleagues, in particular A. Weingart and R.-A. Reissa, focused not only on the activities of the investigator, but also on the work of the expert. ${ }^{40}$

33 Зорин Г.А. Теоретические основы криминалистики [Georgy A. Zorin, Theoretical Basis of Criminalistics] 30-31 (Minsk: Amalfeya, 2000).

34 Ахмедшин Р.Л. Криминалистическая характеристика личности преступника: Дис. ... докт. юрид. наук [Ramil L. Akhmedshin, Criminalistic Characteristics of the Perpetrator: Thesis for a Doctor Degree in Law Sciences] 416 (Tomsk, 2006).

35 Jianhong Liu, Crime Patterns During the Market Transition in China, 45(1) The British Journal of Criminology 613 (2005).

36 Zhonglin Chen \& Kaicheng Huang, Drug Problems in China Recent Trends, Countermeasures, and Challenges, 51(1) International Journal of Offender Therapy and Comparative Criminology 98 (2007).

37 laogang Deng et al., Official Corruption During China's Economic Transition: Historical Patterns, Characteristics, and Government Reactions, 26(1) Journal of Contemporary Criminal Justice 72 (2010).

38 Chau-kiu Cheung, Police and Social Work Preventions of Offending Among At-Risk Youth in Shanghai, 83(1) Children and Youth Services Review 112 (2017).

39 Weingart 2012, at 1-64.

40 Трегубов С.Н.Основы уголовной техники, научно-технические приемы расследования преступлений [Sergey N. Tregubov, Fundamentals of Criminal Techniques, Scientific and Technical Methods of Investigating Crime] 5 (Moscow: LeksEst, 2002). 
In addition, in the works devoted to the "methodology of investigating crimes," Ukrainian criminalists considered different issues, including those related to the functioning of the forensic examination cabinets, the order of the inspection of the scene, and the detection and investigation of traces of substances such as, for example, blood, hair and semen, to name just a few. ${ }^{41}$

Naturally, not only processualists ${ }^{42}$ but also criminalists ${ }^{43}$ paid attention to the work of investigators. For example, scientists studying criminalistic issues devoted their work to the principles of a systematic approach ${ }^{44}$ as well as to its application in criminalistics. ${ }^{45}$ Research on the theory of investigative situation ${ }^{46}$ and criminalistic situology ${ }^{47}$ also aroused interest. Evident progress in the development of the criminalistic theory was made through the works of such scientists as V. Komissarov, ${ }_{1}^{48}$ V. Lavrov, ${ }^{49}$ S. Lavrukhin ${ }^{50}$ I. Luzgin, ${ }^{51}$ L. Samygin ${ }^{52}$ and others. Professor O. Baev's work devoted to modern problems and development areas of criminalistics can be viewed as a certain result of the discussion on the subject of criminalistics. ${ }^{53}$

41 Макаренко Н.П. Техника расследования преступлений [Nikolay P. Makarenko, Crime Investigation Techniques] 5-28 (Kharkov: Yuridicheskoye izdatelstvo NKO USSR, 1925).

42 Ларин А.М. Я - следователь [Alexander M. Larin, I Am an Investigator] 800 (Tula: Avtograph, 2008).

43 Лузгин И.М. Расследование как процесс познания [lgor M. Luzgin, Investigation as a Process of Cognition] 177 (Moscow: Moscow University, 1969).

44 жбанков В.А. Принципы системного подхода в криминалистике и в практической деятельности органов внутренних дел при собирании, исследовании, оценке и использовании доказательств [Victor A. Zhbankov, Principles of the Systematic Approach in Criminalistics and Practical Work of Law Enforcement Bodies When Collecting, Researching, Evaluating and Using Evidence] 109 (Moscow: Moscow University, 1977).

45 Головин А.Ю. Криминалистическая систематика: Монография [Alexander Yu. Golovin, Criminalistic Taxonomy: Monograph] 305 (N.P. Yablokov (ed.), Moscow: LeksEst, 2002).

46 Драпкин Л.Я. Основы теории следственных ситуаций [Leonid Ya. Drapkin, Basics of the Investigative Situation Theory] 165 (Sverdlovsk: Publishing House of Ural University, 1987).

47 Волчецкая Т.С. Криминалистическая ситуалогия: Дис. ... докт. юрид. наук [Tatyana S. Volchetskaya, Criminalistic Situology: Thesis for a Doctor Degree in Law Sciences] 395 (Moscow: Moscow University, 1997).

48 Комиссаров В.И. Криминалистическая тактика: история, современное состояния и перспективы развития [Vladimir I. Komissarov, Criminalistic Tactics: History, Current State and Development Prospects] 192 (Moscow: Yurlitinform, 2009).

49 Лавров В.П. Предмет, история и методология криминалистики [Vladimir P. Lavrov, The Subject, History and Methodology of Criminalistics] 178 (Moscow: Moscow University, 1994).

50 Лаврухин С.В. Предмет, задачи, методы и система криминалистики [Sergey V. Lavrukhin, Subject, Tasks, Methods and System of Criminalistics] 156 (Saratov: Saratov University, 1998).

51 Лузгин И.М. Моделирование при расследовании преступлений [lgor M. Luzgin, Modeling in the Crime Investigation] 152 (Moscow: Moscow University, 1981).

52 Самыгин Л.Д. Расследование преступлений как система деятельности [Lev D. Samygin, Crime Investigation as a System of Activities] 180 (Moscow: Moscow University, 1989).

53 Баев О.Я. Российская криминалистика начала XXI в.: направления развития, современные проблемы // Вестник криминалистики. 2000. № 1. С. 5-10 [Oleg Ya. Baev, Russian Criminalistics at the Beginning of the $21^{\text {st }}$ Century: Directions of Development, Modern Problems, 1 Bulletin of Criminalistics 5 (2000)]. 
In China, scientists paid more and more attention to the activities of the so-called authorities of criminal proceedings. For instance, in recent years, a number of articles and system studies have been devoted to issues about the role of the Chinese police ${ }^{54}$ and the prosecutor's office, ${ }^{55}$ including the cases of abuse of power ${ }^{56}$ in the field of drug control ${ }^{57}$ and the development of investigative files. ${ }^{58}$

In the study of the second object, the question arose again as to what is relevant to the subject matter of the criminal process, and what the criminalists should investigate, especially in those works that have studied the collection, verification and evaluation of evidence.

Additionally, the question arose again as to what the subject of the criminal process refers to, and what the criminalists should examine. The issue is especially relevant because all the scientists studied the collection, verification and evaluation of evidence in their works. ${ }^{59}$

\subsection{Specification of the Subject Matter of Criminalistics Considering Crime Investigation and Prosecution}

In many of the studies mentioned above, criminalistics was also defined as the science of investigating crime. The thought requires some clarification, since criminal procedural law may well be referred to as the science of investigating crime even more than criminalistics. Thus, it can be stated that there are at least two branches of scientific knowledge that study the same object. In our opinion, it is obvious that the terminology of both criminal procedural law and criminalistics should be clarified.

A significant number of monographs devoted to the theoretical issues of investigating crime have been published at present. The authors of this article are representatives of Russian criminal procedural law (also, e.g., O. Andreeva, ${ }^{60} \mathrm{~V}$. Balakshin, ${ }^{61} \mathrm{Yu}$.

54 Zheng Chen, Measuring Police Role Orientations in China: An Exploratory Study, 44(1) International Journal of Law, Crime and Justice 43 (2016).

55 Xifen Lin \& Wei Shen, Reforms to China's Pretrial Detention System: The Role of the Procuratorate, 44(1) International Journal of Law, Crime and Justice 183 (2016).

56 Fenfei Li \& Jinting Deng, The Power and the Misuse of Power by China's Local Procuratorates in Anticorruption, 45(1) International Journal of Law, Crime and Justice 1 (2016).

57 Mengyan Dai, Perceptions About the Police in Drug Control: A Survey of Drug Users in Kunming China, 87(3) The Police Journal: Theory, Practice and Principles 201 (2014).

58 Yu Mou, The Constructed Truth. The Making of Police Dossiers in China, 26(1) Social \& Legal Studies 69 (2017).

$59 \mathrm{Li} \mathrm{Li}$, High Rates of Prosecution and Conviction in China: The Use of Passive Coping Strategies, 42(3) International Journal of Law, Crime and Justice 271 (2014).

60 Андреева О.И. Пределы проявления диспозитивности в уголовном судопроизводстве [Olga I. Andreeva, Limits to Dispositiveness in Criminal Proceedings] 136 (Tomsk: Tomsk University, 2000).

61 Балакшин B.C. Оценка допустимости доказательств в российском уголовном процессе: Монография [Victor S. Balakshin, Assessment of Evidence Permissibility in Russian Criminal Proceedings: Monograph] 384 (Moscow: Yurlitinform, 2016). 
Derishev, ${ }^{62}$ M. Romanovsky, O. Voltornist, I. Mikhailovskaya, ${ }^{63}$ etc.) and criminologists (also, e.g., V. Karagodin, ${ }^{64}$ V. Novik, ${ }^{65}$ A. Cheburenkov, ${ }^{66}$ S. Yakushin ${ }^{67}$ ). Some scientists have approached the solution to the problems in a comprehensive way, considering both procedural and criminalistic issues (e.g. A. Aleksandrov, S. Grishin, ${ }^{68} \mathrm{O}$. Baev, ${ }^{69} \mathrm{E}$. Ezhova, ${ }^{70}$ S. Rossinsky, ${ }_{1}^{11}$ I. Smirnov ${ }^{72}$ and others).

However, after examining the works cited, it becomes obvious that, firstly, they do not cover all the issues faced at the investigation and trial of criminal cases. Secondly, in the study of the common object of cognition, the subject areas of criminal procedural science and criminalistics are not clearly defined.

We share the position of those authors who, when examining the investigator's activities, indicate the substantive aspects to be investigated. ${ }^{73}$

62 Деришев Ю.В., Романовский М.Э., Волторнист О.А. Проблемы соотношения досудебного и судебного производства в уголовном процессе России [Yury V. Deryshev et al., Problems of Correlation of Pre-Trial and Judicial Proceedings in Criminal Procedure of Russia] 168 (Moscow: Yurlitinform, 2009).

63 Михайловская И.Б. Настольная книга судьи по доказыванию в уголовном процессе [Inga B. Mikhailovskaya, Judges' Handbook on Proof in Criminal Proceedings] 192 (Moscow: Velbi; Prospekt, 2006).

64 Карагодин В.Н. Основы методики расследования умышленных убийств: Учебное пособие [Valery N. Karagodin, Basics of the Methodology for Investigating Intentional Homicide: Textbook] 244 (Yekaterinburg: Raritet, 2010).

65 Новик В.В. Криминалистические аспекты доказывания по уголовным делам: проблемы теории и практики [Valery V. Novik, Criminalistic Aspects of Proving in Criminal Cases: Theory and Practice] 471 (St. Petersburg: Yuridicheskiy tsentr Press, 2005).

66 Чебуренков А.А. Основы теории расследования: Монография [Alexander A. Cheburenkov, Fundamentals of Investigation Theory: Monograph] 176 (Moscow: Yurlitinform, 2010).

67 Якушин С.Ю. Тактические задачи и средства их решения при расследовании преступлений [Stanislav Yu. Yakushin, Tactical Tasks and Means for Their Solution in the Crime Investigation] 322 (V.N. Karagodin (ed.), Kazan: Kazan University, 2014).

68 Александров А.С., Гришин С.П. Перекрестный допрос: Учебно-практическое пособие [Aleksander S. Aleksandrov \& Sergey P. Grishin, Cross-Examination: Training Manual] 296 (Moscow: Velbi; Prospekt, 2005).

69 Баев О.Я. Уголовно-процессуальное исследование преступлений: проблемы качества права и правоприменения [Oleg Ya. Baev, Criminal Procedural Investigation of Crimes: Problems of the Quality of Law and Enforcement] 288 (Moscow: Yurlitinform, 2009).

70 Ежова Е.В. Проблемы раскрытия преступлений в современной России: Монография [Elena V. Ezhova, Problems of Crime Detection in Modern Russia:Monograph] 226 (Ufa: Bashkir State University, 2008).

71 Россинский С.Б. Результаты «невербальных» следственных и судебных действий как вид доказательств по уголовному делу: Монография [Sergey B. Rossinsky, The Results of "Non-Verbal" Investigative and Judicial Actions as a Form of Evidence in a Criminal Case: Monograph] 224 (Moscow: Yurlitinform, 2015).

72 Особенности расследования отдельных категорий уголовных дел и уголовных дел в отношении отдельных категорий лиц: Монография [Investigation of Certain Categories of Criminal Cases and Criminal Cases in Relation to Certain Categories of Persons: Monograph] 336 (I.G. Smirnova (ed.), Moscow: Yurlitinform, 2016).

73 Попов И.А. Расследование пожаров: Правовое регулирование. Организация и методика:Учебное пособие [Ivan A. Popov, Fire Investigation: Legal Regulation. Organization and Methodology: Textbook] 310 (Moscow: YurlnfoR, 1998). 
It is quite obvious that attempts to comprehensively study the objects of cognition of criminal legal sciences without specifying the subjects of jurisdiction will not differ in depth and in the systematic presentation of the results obtained.

For the same reason, it is not entirely true to state that the subject of criminalistic scientific research is the investigation activity pattern without mentioning that these regularities are also studied by other criminal law sciences. ${ }^{74}$

In the process of examination, the functional side of the object under consideration should also be singled out, which means not only the criminalistic description of the investigator's activity, but also the criminalistic characteristics of the judicial examination of criminal cases ${ }^{75}$ or criminalistic activity, ${ }^{76}$ which seems more accurate.

In this respect, it is possible to use the positive experience accumulated by scientists from China. In particular, when studying the so-called alternative methodology and critical analysis, ${ }^{77}$ the shortest path algorithms are used to identify associations in criminal networks $^{78}$ and develop intelligent decision-making models. ${ }^{79}$

We believe that criminalistic activity is aimed at establishing the circumstances that have to be proven, principally the events of the crime, including its trace pattern and the mechanism of committing crime, especially taking into account the progress in electronic document management.

On the other hand, the circumstances that are subject to proof are established by the criminal process participants who possess power. Consequently, they are the subjects that carry out criminalistic activities. This statement does not exclude the possibility of using the achievements of criminalistics by other participants in the criminal process, e.g. a lawyer. However, the latter does not conduct any criminalistic activities.

74 Севрюков В.В. Основы криминалистической методики расследования преступлений, совершаемых бандами: Автореф. дис. ... канд. юрид. наук [Vyacheslav V. Sevryukov, Fundamentals of the Criminalistic Methodology for Investigating Crimes Committed by Gangs: Synopsis of a Thesis for a Candidate Degree in Law Sciences] 6 (Barnaul: Altai State University, 2004).

75 Гавло В.К., Ким Д.В. Криминалистическая характеристика судебного рассмотрения уголовных дел: проблемы становления и развития (исторический аспект) // Уголовно-процессуальные и криминалистические чтения на Алтае: Материалы научно-практической конференции [Veniamin K. Gavlo \& Dmitry V. Kim, Criminalistic Characteristics of Judicial Consideration of Criminal Cases: The Problems of Formation and Development (Historical Aspect) in Criminal Procedure and Criminalistic Readings in Altai: Materials of the Scientific-Practical Conference] 36-44 (Barnaul: Altai State University, 2005).

76 Криминалистика: Учебник [Criminalistics: Textbook] 24-27 (N.P. Yablokov (ed.), $3^{\text {rd }}$ ed., Moscow: Yurist, 2005).

77 Jianhua Xu et al., Doing Criminological Ethnography in China: Opportunities and Challenges, 17(2) Theoretical Criminology 271 (2013).

78 Jennifer J. Xu \& Hsinchun Chen, Fighting Organized Crimes: Using Shortest-Path Algorithms to Identify Associations in Criminal Networks, 38(3) Decision Support Systems 473 (2004).

79 Sheng-Tun Li et al., An Intelligent Decision-Support Model Using FSOM and Rule Extraction for Crime Prevention, 37(10) Expert Systems with Applications 7108 (2010). 
Taking into account the criminalistic activity subjects, the object under consideration can be properly defined as the activity of investigation and judicial proceeding. The regular methods and techniques selected in the object under consideration form the content of the criminalistic activity.

Material criminal law regulates public relations through criminal prohibitions on committing socially dangerous acts under the threat of criminal sanctions. Criminal procedure is a "form" of material criminal law. The distinction between criminalistic activity and the activity of criminal procedure also seems quite logical. Within criminal procedure "form" of activity there is some criminalistic "content." Finding trace information about the crime does not mean that it constitutes proof. The task of criminalistics is to ensure the transition from trace information to evidence through its detection, qualitative recording, and fixation in the procedural document.

\section{Interrelation of Objects of Cognition in Criminalistics}

The scientific and educational literature emphasizes the unity of the examined objects of cognition. For example, N. Yablokov underlines the relationship of the dual object of knowledge - "criminal activity and criminalistic activity for its investigation and prevention."180

The position of M. Kaminsky is also interesting. He believes that the structure of criminal activities and the structure of the crime investigation must dovetail according to the methodological principle of isomorphism ("mirror image"). ${ }^{81}$ The correlation between objects of cognition in criminalistics is also emphasized in later works of the scientist. ${ }^{22}$

On the empirical and theoretical levels of cognition, the relationship between the objects is supposed to be as follows: first comes the criminal (as the first object of knowledge). A participant in the process possessing authority (the second object of knowledge) learns of a single offense and a criminal retrospectively according to the traces left (material and non-physical). Direct contact with the crime is often

80 Criminalistics: Textbook, supra note 22, at 23-27.

81 Каминский М.К. Криминалистическая характеристика деятельности по выявлению, раскрытию и расследованию преступлений // Правовые и общественно-экономические науки и борьба с хищениями социалистического имущества [Marat K. Kaminsky, Criminalistic Characteristics of the Activities to Identify, Uncover and Investigate Crime in Legal and Socio-Economic Sciences and Combating the Theft of Socialist Property] 153-158 (Gorky: High School MVD USSR, 1977).

82 Каминский М.К. Современные проблемы криминалистической идентификации в свете работ профессора А.И. Винберга // Значение творческого наследия профессора А.И. Винберга в развитии отечественной криминалистики (к 100-летию со дня рождения): Сборник материалов 49-х Криминалистических чтений [Marat K. Kaminsky, Modern Problems of Criminalistic Identification in the Light of Professor A.I. Vinberg's Works in The Importance of the Creative Heritage of Prof. A.I. Vinberg in the Development of National Criminalistics (on the Occasion of the $100^{\text {th }}$ Anniversary of His Birth): Collection of Materials of the $49^{\text {th }}$ Criminalistic Readings] 40 (Moscow: Academy of Management of the Russian Ministry of Internal Affairs, 2008). 
possible only through the material evidence that is left at the scene. The results of the examination of the trace evidence help to establish a picture of what happened, and the mechanism of committing crime becomes known. In the course of empirical scientific generalization, scientists create an abstract model - a criminalistic description of the crime (criminal activity) that takes into account, among other things, the typological characteristics of the criminal with consideration of his/her criminal specialization. Then criminalistic regularities are determined in the activity of the investigator and the court: the standard versions, situations and the activity algorithm. On this basis, a particular criminalistic methodology for investigating and prosecuting specific types or groups of crimes is developed. The obtained scientific knowledge is specified in the course of the subsequent generalization of the investigative and judicial practice as well as the positive experience and errors in the investigation and judicial examination of specific crimes.

In fact, the information about the crime and the perpetrator reflected in the trial helps to solve the crime through the achievements of criminalistics. Therefore, it is the information that needs scientific understanding; this information lies at the heart of the subject of criminalistics and criminalistic research.

Notably, establishing the mechanism of committing crime (criminal activity) by a participant in a criminal process with powers at the pre-trial stage, even with his/ her internal conviction that the person charged is guilty of committing the offense, by virtue of the presumption of innocence, does not mean that a guilty verdict will be returned, since the court can come to a different conclusion.

Obviously, the legal sciences of the criminal law cycle are interrelated in considering the objects of cognition, especially crime (criminal activity) and the criminal. It is worth repeating that the information relating to the subject of criminalistics should be identified. Obtaining and subsequent generalization of the information significant for criminalistics make it possible to characterize (make a model of) any kind (group) of crime.

At the same time, not only crime itself, as an act of human behavior, is of interest to criminologists. Besides findings about the crime commission, criminalistics considers information about the crime preparation and concealment, the trace pattern of the case, the offender's behavior both before and after the offense, and the interaction of living and inanimate objects in the mechanism of committing crime. However, some criminalistic details may not be included in the object of evidence. In this regard, the term "criminalistic characteristics of crime" is of a conditional nature, because the sphere of interest of criminalistics often goes beyond the scope of the crime itself. Since the term "criminal activity" has long been used in criminal law, it is possible to use the term "criminalistic characteristics of a criminal activity" in criminalistics in this context. The introduction of such a concept emphasizes the general object of study and the difference between criminalistic knowledge and the knowledge of other criminal sciences. 
By criminalistic characteristics of an offense (a criminal activity) we mean a set of generalized, criminalistically significant information about the system of interacting and interdependent elements in the mechanism of committing crime (criminal activity); the elements form the standard trace evidence of a crime event.

The knowledge of typical trace evidence, in its turn, allows evaluating specific trace information on a practical level; on its basis, a conclusion is made about the presence or absence of other elements in the mechanism of committing crime (criminal activity). Establishing the relationship with other elements of the mechanism of committing crime helps to solve it and to cope with other tasks of the investigation.

\section{Positions on the Relationship of Criminal Sciences in Some Countries of Europe and in China}

As previously noted, scientists from Eastern Europe have very similar views regarding the definition of the subject of criminalistics. For example, a well-known Lithuanian criminalist, $\mathrm{H}$. Malevski, generally sharing the ideas of the authors of this article, proposes to separate one part in criminalistics, i.e. the criminalistic strategy. ${ }^{83}$

A scientist from Ukraine, V. Shepitko, has a position which is similar in meaning and content. Having analyzed the experience of Russian colleagues, the criminalist reasonably concludes that the relevant objectives of criminalistics in modern conditions are: the interpenetration of criminalistics and the practice of law enforcement agencies; the introduction of innovations in practical activities; the development of the latest "product" of criminalistics for practice; and some others. ${ }^{84}$

Polish colleagues are also working to determine the prospects for the development direction of criminalistics. Through the prism of their pilot survey, changes in practical criminalistics have been revealed and conclusions made regarding trends in its development. They include the modernization of research methods of traces in criminalistic analysis and prognosis. The prospects for the development of criminalistics have also been predicted. ${ }^{85}$

H. Ditrich, a German scientist, also investigated the subject matter of criminalistics, drawing attention to its connection with forensic expert activity. ${ }^{86}$

In addition to our European colleagues, special mention should be made of issues related to the improvement of the system of law enforcement practice in the People's

83 Hendryk Malevski, Criminalistic Strategy, Strategy in Criminalistics or Strategy of Criminal Policy?, 13 Criminalistics and Forensic Expertise: Science, Training, Practice 31 (2013).

84 Valery Shepitko, The Subject, System and Objectives of Criminology in the XXI Century, 13 Criminalistics and Forensic Expertise: Science, Training, Practice 33 (2013).

85 Grażyna Kędzierska, Meanders of Criminology of the $27^{\text {st }}$ Century, 13 Criminalistics and Forensic Expertise: Science, Training, Practice 45 (2013).

86 Hans Ditrich, How "Scientific" is "Forensic Science"?, 8 Criminalistics and Forensic Expertise: Science, Training, Practice 20 (2012). 
Republic of China. The criminal procedural law and special means of combating crime in China seem to be well developed. ${ }^{87}$ They have many similar approaches to those of their Russian colleagues ${ }^{88}$ However, in contrast to Russian criminal procedure legislation, China should establish an objective truth in the investigation of a criminal case through special forensic means, which is absolutely justified and correct. ${ }^{89}$

To conclude, the approaches in Russia, some countries of Europe, and China to the issues of combating crime by applying criminalistic techniques seem to have many common features as well as differences.

\section{Conclusion}

The integrative nature of criminalistics does not imply any unreasonable "intrusion" into the subject areas of the other legal sciences of the criminal law cycle. What is necessary is to differentiate knowledge in the study of common objects of cognition.

Attempts to comprehensively study the objects of cognition of criminal law without specifying the subjects of reference will not excel at profound and systematic presentation of the results obtained.

Differentiating knowledge in the study of common objects of cognition is one of the main issues both in criminal science and in any other branch of scientific knowledge. One of the ways to solve this is to determine the criteria for distinguishing the subject of criminalistics from the subjects of other legal sciences in the criminal law cycle. Such criteria can, for example, be the goals and objectives of cognition. The aim of cognition in criminalistics in its turn is the establishment of trace evidence of a crime scene, and, accordingly, the task is to find and work with material and nonphysical crime traces.

Specification of the regularities included in the subject of criminalistics makes it possible to define it in a more accurate way. It is often difficult to do this without defining the nature of the science. The majority of Russian scientists consider criminalistics to be a special legal discipline. However, there also exist proponents of the non-legal nature of criminalistics, who advocate dividing all the legal sciences into legal and non-legal disciplines; only branch legal sciences can be recognized as legitimate. They state that criminalistics belongs to non-legal sciences, since it

87 Lening Zhang et al., Criminological Research in Contemporary China: Challenges and Lessons Learned From a Large-Scale Criminal Victimization Survey, 51(1) International Journal of Offender Therapy and Comparative Criminology 110 (2007).

88

Ninghua Wang et al., Analyzing Crime Displacement with a Simulation Approach, 41(2) Environment and Planning B: Urban Analytics and City Science 359 (2014).

89 Миньянь Л. Совершенствование системы уголовного судопроизводства Китая // Вестник Бурятского государственного университета. 2015. № 2(1). С. 173-176 [Liang Minyan, Development of a System of Criminal Legal Proceedings in China, 2(1) Bulletin of Buryat State University 173 (2015)]. 
does not have its own system of rules of law regulating social relations arising in its domain. ${ }^{90}$

The point of view relating to the non-legal nature of criminalistics is also common among our European colleagues. For instance, some German scientists believe that criminalistics belongs to the criminal sciences, and, along with criminology, is a nonlegal science. ${ }^{91}$

Such a position does not seem to be correct. Particularly in Russia, the theory of police work, forensics expertise, together with criminalistics comprise the scientific specialty coded 12.00.12; they have their own system of rules of law, and as a kind of state activity exist alongside the activity of criminal procedure. Moreover, at all stages of operational-search, forensic and criminal-procedure activities, the scientific potential of criminalistics is used directly, and the usage is exclusively of a legal nature, that is to say, in the work of the crime scene investigator, criminalistic experts, during the criminalistic examinations, etc. Consequently, it is quite reasonable to speak of criminalistic activity, which is currently regulated not only by criminal procedure and operational-search legislation as well as the law on forensic activity, but also by subordinate regulatory Acts. Through the prism of the structural and system approach, it is quite logical to develop and adopt a federal law that will regulate the criminalistic activity issues.

Thus, criminalistics is a special legal science of the criminal law cycle about the regularities of the mechanism of committing crime, its reflection in material traces and ideal images, and the activity based on this knowledge aimed at the implementation of the criminal justice process by criminalistic methods and means.

Unanimity of scientific views on the subject matter of criminalistics and its nature can be considered a positive trend, a unifying factor that will lay the foundation for developing a single criminalistic science area in Russia, Europe and the BRICS countries (on the example of the People's Republic of China). Moreover, the countries of Europe have already begun work in this direction and in 2011 conceptually formulated the idea of creating a single "forensic science" area 2020.92

90 Лаврухин С.В. Природа криминалистики и вопросы правоприменения // Криминалистика в системе правоприменения: Материалы конференции (Москва, МГУ им. М.В. Ломоносова, 27-28 октября 2008 г.) [Sergey V. Lavrukhin, The Nature of Forensic Science and Law Enforcement Issues in Forensic Science in the Law Enforcement System: Conference Papers (Moscow, Lomonosov Moscow State University, 27-28 October 2008)] 50-51 (Moscow: MAKS Press, 2008).

91 Rolf Ackermann et al., Zum Stellenwert der Kriminalistik, Artikelserie in Kriminalistik, H. 9-12/2000 32 (Heidelberg: Kriminalistik Verlag, Hüthig GmbH \& Co., 2001).

92 Council of the European Union, Council Conclusions on the Vision for European Forensic Science 2020 Including the Creation of a European Forensic Science Area and the Development of Forensic Science Infrastructure in Europe, $3135^{\text {th }}$ Council meeting, Justice and Home Affairs, Brussels, 13-14 December 2011 (Nov. 2, 2018), available at https:// www.consilium.europa.eu/uedocs/cms_data/ docs/pressdata/en/jha/126875.pdf. 
The creation of a single criminalistic area of Russia and China looks even more prospective due to the identity of national legislations regulating the issues of combating crime and strengthening interstate cooperation in recent years.

Joint scientific research in the field of so-called cyberterrorism ${ }^{93}$ looks very promising as well as the collection of digital evidence which is already being done by scientists from China ${ }^{94}$ and Russia. ${ }^{95}$ Research cooperation will enhance the efficiency of law enforcement activities in Russia and abroad. This will enable the development of common approaches to theoretical issues and combating crime, especially international crime, which is known to have no borders.

\section{References}

Chen Z. \& Huang K. Drug Problems in China Recent Trends, Countermeasures, and Challenges, 51(1) International Journal of Offender Therapy and Comparative Criminology 98 (2007).

Chen Z. Measuring Police Role Orientations in China: An Exploratory Study, 44(1) International Journal of Law, Crime and Justice 43 (2016).

Cheung C. Police and Social Work Preventions of Offending Among At-Risk Youth in Shanghai, 83(1) Children and Youth Services Review 112 (2017).

Dai M. Perceptions About the Police in Drug Control: A Survey of Drug Users in Kunming China, 87(3) The Police Journal: Theory, Practice and Principles 201 (2014).

Deng I. et al. Official Corruption During China's Economic Transition: Historical Patterns, Characteristics, and Government Reactions, 26(1) Journal of Contemporary Criminal Justice 72 (2010).

Jiang S. \& Lambert E.G. Views of Formal and Informal Crime Control and Their Correlates in China, 19(1) Lambert, International Criminal Justice Review 5 (2009).

Li F. \& Deng J. The Power and the Misuse of Power by China's Local Procuratorates in Anticorruption, 45(1) International Journal of Law, Crime and Justice 1 (2016).

Li L. High Rates of Prosecution and Conviction in China: The Use of Passive Coping Strategies, 42(3) International Journal of Law, Crime and Justice 271 (2014).

93 Bin Liang \& Hong Lu, Internet Development, Censorship, and Cyber Crimes in China, 26(1) Journal of Contemporary Criminal Justice 103 (2010).

94 Shiuh-Jeng Wang, Measures of Retaining Digital Evidence to Prosecute Computer-Based Cyber-Crimes, 29(2) Computer Standards \& Interfaces 216 (2007).

95 Вехов В.Б. Понятие, виды и особенности фиксации электронных доказательств // Расследование преступлений: проблемы и пути решения. 2016. № 1. С. 155-158 [Vitaly B. Vekhov, The Concept, Types and Peculiarities of Fixing Electronic Evidence, 1 Investigation of Crimes: Problems and Solutions 155 (2016)]; Вехов В.Б. Работа с электронными доказательствами в условиях изменившегося уголовно-процессуального законодательства // Российский следователь. 2013. № 10. С. 22-24 [Vitaly B. Vekhov, Work with Electronic Evidence in the Changed Criminal Procedure Legislation, 10 Russian Investigator 22 (2013)]. 
Liang B. \& Lu H. Internet Development, Censorship, and Cyber Crimes in China, 26(1) Journal of Contemporary Criminal Justice 103 (2010).

Lin X. \& Shen W. Reforms to China's Pretrial Detention System: The Role of the Procuratorate, 44(1) International Journal of Law, Crime and Justice 183 (2016).

Liu J. Crime Patterns During the Market Transition in China, 45(1) The British Journal of Criminology 613 (2005).

Liu L. \& Li J.C.M. Progress and Future Directions of Crime Research in China with Selected Case Studies, 4(1) Journal of Research in Crime and Delinquency 213 (2017).

Mei J. \&Wang M. Social Change, Crime, and Criminology in China, 23(1) Crime \& Justice International 14 (2007).

Mou Y. The Constructed Truth. The Making of Police Dossiers in China, 26(1) Social \& Legal Studies 69 (2017).

Wang N. et al. Analyzing Crime Displacement with a Simulation Approach, 41(2) Environment and Planning B: Urban Analytics and City Science 359 (2014).

Xu J. et al. Doing Criminological Ethnography in China:Opportunities and Challenges, 17(2) Theoretical Criminology 271 (2013).

Xu J.J. \& Chen H. Fighting Organized Crimes: Using Shortest-Path Algorithms to Identify Associations in Criminal Networks, 38(3) Decision Support Systems 473 (2004).

Zhang L. et al. Criminological Research in Contemporary China: Challenges and Lessons Learned From a Large-Scale Criminal Victimization Survey, 51(1) International Journal of Offender Therapy and Comparative Criminology 110 (2007).

\section{Information about the authors}

Evgeny Smakhtin (Tyumen, Russia) - Professor, Department of Criminal Law and Procedure, Tyumen State University (38 Lenina St., Tyumen, 625000, Russia; e-mail:smaxt@yandex.ru).

Roman Sharapov (St. Petersburg, Russia) - Professor, St. Petersburg Law Institute (Branch) of the Federal Establishment of Higher Education University of the Office of the Prosecutor of the Russian Federation (44 Liteiny Av., St. Petersburg, 191104, Russia; e-mail: srd72@mail.ru). 